УДК 664.65:664.664.33

\title{
REASONING OF IMPROVED FLOWCHART FOR PRODUCTION OF SPECIALLY BAKED RUSK FLOUR
}

\author{
V. Makhynko, L. Makhynko, I. Melnyk \\ National University of Food Technologies
}

\begin{tabular}{|c|c|}
\hline Key words: & ABSTRACT \\
\hline $\begin{array}{l}\text { rusk flour, } \\
\text { bread crumbs, } \\
\text { equipment, } \\
\text { technology, } \\
\text { improvement }\end{array}$ & $\begin{array}{l}\text { Rusk flour is a bread product which becomes more and more } \\
\text { in demand every year. This is primarily due to a large number of } \\
\text { various frozen semi-finished meat and fish products on the mar- } \\
\text { ket that are becoming increasingly popular among consumers. In } \\
\text { these semi-finished products manufacture technology, rusk flour }\end{array}$ \\
\hline $\begin{array}{l}\quad \text { Article history: } \\
\text { Received } 08.04 .2020 \\
\text { Received in revised form } \\
24.04 .2020 \\
\text { Accepted } 21.05 .2020\end{array}$ & $\begin{array}{l}\text { can be used not only for decoration (to give a certain color or } \\
\text { even flavor). It is aimed at retaining the moisture released when } \\
\text { the products are heated while ensuring formation of brown crust } \\
\text { and preserving juicy structure. } \\
\text { Bread crumbs made by grinding usual dried bakery products }\end{array}$ \\
\hline $\begin{array}{l}\text { Corresponding author: } \\
\text { mavam78@gmail.com }\end{array}$ & $\begin{array}{l}\text { are most commonly used as rusk flour. However, organoleptic, } \\
\text { physical and chemical features of such bread crumbs are not } \\
\text { uniform and can vary significantly from batch to batch. These } \\
\text { indicators are also very hard to control (for example, to ensure } \\
\text { that crumbs have a certain color). So, production of specially } \\
\text { baked rusk flour is more promising here. The article covers the } \\
\text { technology to make such flour which involves baking special } \\
\text { breads (bread sticks) and their subsequent cooling, grinding, } \\
\text { drying, and calibration of the resulting crumbs. The technology } \\
\text { can ensure uniformity of quality of the final products and their } \\
\text { ability to satisfy the most diverse consumers' needs. } \\
\text { The purpose of the work was to identify the production "bot- } \\
\text { tlenecks" and to develop measures and proposals to improve the } \\
\text { existing process flowchart. It uses a specific example where the } \\
\text { main limiting production factors are established, and proposes a } \\
\text { number of measures to overcome them. It shows that broad } \\
\text { mechanization of core and auxiliary operations not only ensures } \\
\text { growth of the enterprise capacity, but also reduces the amount of } \\
\text { physically demanding labor, and allows to avoid night shifts. Use } \\
\text { of modern equipment can also significantly reduce technological } \\
\text { losses and increase cost-effectiveness of the production. The } \\
\text { article proposes a promising flowchart that can be implemented } \\
\text { both in large enterprises and in small-capacity workshop. }\end{array}$ \\
\hline
\end{tabular}

DOI: $10.24263 / 2225-2916-2020-27-8$

(C) В. М. Махинько, Л. В. Махинько, А. І. Мельник, 2020 


\title{
ОБГРУНТУВАННЯ УДОСКОНАЛЕНОЇ СХЕМИ ВИРОБНИЦТВА СПЕЦІАЛЬНО ВИПЕЧЕНИХ ПАНІРУВАЛЬНИХ СУХАРІВ
}

\author{
В. М. Махинько, д-р. техн. наук \\ Л. В. Махинько, канд. технт. наук \\ І. А. Мельник \\ Національний університет харчових технологій
}

У статті виявлено «вузькі місця» виробництва та розроблено заходи і пропозиції щодо удосконалення наявної апаратурно-технологічної схеми. На конкретному прикладі встановлено основні обмежувальні фрактори виробництва і запропоновано ряд заходів для їх подолання. Показано, що широке впровадження механізації основних і допоміжних операцій забезпечить не лише зростання потужності підприємства, але й зменшить кількість важкої фрізичної праці, надасть можливість відмовитися від роботи у нічний час. Використання сучасного обладнання здатне також суттєво зменшити технологічні втрати, підвищивши рентабельність виробництва. Використання запропонованої схеми є перспективним і може бути впроваджене як на великих підприємствах, так і в цехах невеликої потужності.

Ключові слова: панірувальні сухарі, хлібна крихта, обладнання, технологія, удосконалення.

Постановка проблеми. Темп життя сучасної людини ставить особливі вимоги до харчової промисловості щодо розроблення нових продуктів, нескладних і швидких у приготуванні. Останнім часом набувають все більшої популярності такі вироби, як заморожені напівфабрикати з м' яса чи риби. Вони здатні тривалий час зберігатися без втрати споживчих властивостей і водночас дуже легкі в приготуванні. Науковцями харчової галузі проводиться значна робота щодо удосконалення вже існуючих рецептур таких виробів і розроблення нових [1-3]. За останні десятиліття в Україні побудовано декілька великих промислових підприємств з випуску заморожених напівфабрикатів потужністю понад 100 т/добу. Для виробництва такого обсягу продукції вони мають бути забезпечені достатньою кількістю сировини, стабільної за основними органолептичними та фізико-хімічними показниками. Одним iз важливих рецептурних компонентів заморожених м'ясних і рибних напівфабрикатів є панірувальна крихта. Її функції досить різноманітні: надання певного зовнішнього вигляду (колір, структура), формування чи підсилення смаку і структури. Але насамперед паніровка забезпечує вирішення технологічних завдань: запобігання прилипанню виробів до гріючої поверхні, зв’язування вологи, що виділяється при розігріванні виробів, забезпечення формування рум'яної кірочки і збереження соковитої структури. Тож до якості панірувальних сухарів ставляться підвищені вимоги [4]. Значна частина крихти для панірування виготовляється 3 попередньо висушених традиційних хлібобулочних виробів. Це забезпечує ії низьку вартість, однак обмежує діапазон характеристик, що можуть регулюватися на етапі іiі одержання. Водночас виробники заморожених напівфабрикатів, ідучи назустріч побажанням споживачів і відповідаючи на конкурентні виклики ринку, намагаються увесь раз розширювати асортимент, розробляючи вироби з новим зовнішнім виглядом i смаком. У цьому випадку панірувальна крихта, виготовлена за традиційної схемою, 
не здатна виконати всіх покладених на неї функцій. Тож розроблення чи удосконалення схеми виготовлення спеціально випечених панірувальних сухарів $є$ актуальним і перспективним завданням для фахівців харчової галузі.

На попередніх етапах досліджень проведено комплексне оцінювання органолептичних і фізико-хімічних показників хлібної крихти, наявної на вітчизняному ринку [5]. Встановлено, що вона характеризується суттєвою відмінністю як за кольором, так і за основними характеристиками (крупністю, насипною густиною, кутом природного схилу). Це зумовлено насамперед якістю хлібної сировини, з якої ії отримують, а також особливостями організації технологічного процесу. Потреба отримувати крихту лише певного розміру призводитиме до утворення великої кількості відходів, а цілеспрямоване регулювання забарвлення кінцевої продукції згідно 3 потребами замовника за наявної технології іiі виготовлення практично неможливе. Значно перспективнішим є спосіб виготовлення спеціально випечених панірувальних сухарів. У цьому разі з'являється можливість цілеспрямованого формування їх основних фізико-хімічних показників і забезпечення необхідного кольору згідно зі сформульованими замовником вимогами.

Метою статті є вивчення існуючої схеми виробництва спеціально випечених панірувальних сухарів, виявлення «вузьких місць» виробництва та розроблення заходів і пропозицій щодо удосконалення наявної апаратурно-технологічної схеми.

Матеріали і методи. На прикладі підприємства 3 виготовлення спеціально випечених панірувальних сухарів ТОВ «Дивалл-Плюс» розглянуто існуючу схему організації технологічного процесу, особливості роботи підприємства і наявне технологічне обладнання. Із залученням елементів системного аналізу складено функціональну й апаратурну схеми, встановлено обмежувальні фактори виробництва. Для удосконалення основних і допоміжних операцій технології виготовлення спеціально випечених панірувальних сухарів використано сучасні розробки у сфері обладнання і організації виробничих процесів.

Результати досліджень. Серед виробників спеціально випечених панірувальних сухарів лідером на сьогодні $є$ ТОВ «Боярд-Плюс» (м. Боярка, Київської обл.). Підприємство є основним постачальником панірувальної крихти для таких відомих виробників заморожених напівфабрикатів, як Миронівский м'ясопереробний завод (ТМ «Легко», м. Київ) та «Срмолино» (Дніпропетровська обл.). Також підприємство реалізує продукцію під власною торговельною маркою «Паніровка» і співпрацює 3 TM «Cykoria S. А.» (Польща). Виробничий підрозділ, що спеціалізується на виробництві саме спеціально випечених панірувальних сухарів, - це ТОВ «ДиваллПлюс», розташоване у м. Васильків Київської області. Ознайомлення з роботою підприємства та основними технологічними операціями дали змогу скласти функціональну схему виробництва, наведену на рис. 1 .

Підприємство оснащене сучасним обладнанням відомих закордонних виробників, тому здатне задовольняти найвибагливіші потреби замовників щодо розміру та кольору крихти. На сьогодні підприємство випускає понад 10 видів крихти розміром від 0,5 до 4 мм різноманітних кольорів (у т.ч. зеленого і рожевого). Висока якість і стабільні фізико-хімічні показники крихти спричиняють постійне зростання попиту на цей продукт. А це, у свою чергу, вимагає нарощування потужності підприємства. За цих умов виявляються обмежувальні фактори виробництва, одним із найголовніших серед яких є низький рівень механізації допоміжних операцій. 


\begin{tabular}{|c|}
\hline $\begin{array}{c}\text { Підготовка сировини } \\
\text { (борошно, вода, дріжджі, сіль, смако-ароматичні добавки та барвники) }\end{array}$ \\
\hline 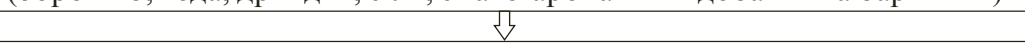 \\
\hline Замішування тіста \\
\hline$\checkmark$ \\
\hline Бродіння тіста \\
\hline 可 \\
\hline Формування тістових батонів \\
\hline पू \\
\hline Випікання батонів \\
\hline तु \\
\hline Охолодження батонів \\
\hline Z \\
\hline Подрібнення батонів (одержання крихти грубого подрібнення) \\
\hline V \\
\hline Випікання/висушування крихти грубого подрібнення \\
\hline Vy \\
\hline Охолодження крихти грубого подрібнення \\
\hline$\sqrt{2}$ \\
\hline Розмелювання крихти (одержання крихти дрібного подбірнення) \\
\hline V \\
\hline Калібрування крихти на фракції за розміром \\
\hline $\mathrm{V}$ \\
\hline Тарування крихти \\
\hline
\end{tabular}

Рис. 1. Принципова схема виготовлення спеціально випечених панірувальних сухарів

До таких «вузьких місць» можна віднести:

- тарний спосіб отримання і зберігання борошна з ручним розвантаженням автотранспорту;

- дозування всієї сировини на замішування тіста вручну, що не лише подовжує тривалість процесу, але й знижує його точність;

- випікання батонів у печах ротаційного типу, що зумовлює потребу ручного укладання тістових заготовок на листи вагонеток і ручного завантаження/вивантаження печей;

- ручне завантаження крихти першого подрібнення на листи для підсушування і їх подальше розвантаження;

- ручне дозування готової крихти у мішки.

Суттєвою вадою наявної на підприємстві апаратурно-технологічної схеми $є$ повна відсутність механізації допоміжних операцій. Це призвело до того, що вручну здійснюються такі постійні технологічні операції, як:

- переміщення тіста від тістомісильної машини до екструдера; нення;

- транспортування крихти першого подрібнення до млинка остаточного подріб-

- переміщення подрібненої крихти до калібратора.

Наявність зазначених недоліків зумовлює необхідність великої кількості ручної праці й роботи в нічні зміни, аби задовольнити зростаючий попит на продукцію цеху. Відомо, що підвищення потужності підприємства може здійснюватися двома способами: екстенсивним (коли збільшується кількість виробничих площ, встановлюється більша кількість однотипного обладнання за незмінного рівня ефективності праці) чи інтенсивним (коли зростання потужності забезпечується поліпшенням 
форм і методів організації роботи). Світовий досвід свідчить, що саме другий шлях $\epsilon$ безумовно перспективнішим. I приклад суміжних галузей виробництва (хлібопекарської, кондитерської, макаронної, харчоконщентратної) переконує, що для інтенсивного нарощування потужності на ринку є всі необхідні засоби та обладнання. На основі вивчення досвіду ряду вітчизняних і зарубіжних підприємств пропонуються такі заходи щодо удосконалення наявної схеми організації виробництва:

- перехід на безтарний спосіб підвезення, перекачування і зберігання борошна за рахунок встановлення тканинних силосів і систем пружинного транспортування борошна типу «спіроматик»;

- автоматичне дозування борошна і встановлення тістомісильної машини з автоматичним вивантаженням тіста;

- використання печі тунельного типу, що дасть змогу механізувати процеси іiі завантаження/вивантаження і полегшить обслуговування;

- встановлення транспортуючих пристроїв пружинного чи стрічкового типу на більшість допоміжних ділянок.

3 урахуванням цих пропозицій розроблена удосконалена схема виробництва спеціально випечених панірувальних сухарів (рис. 2).

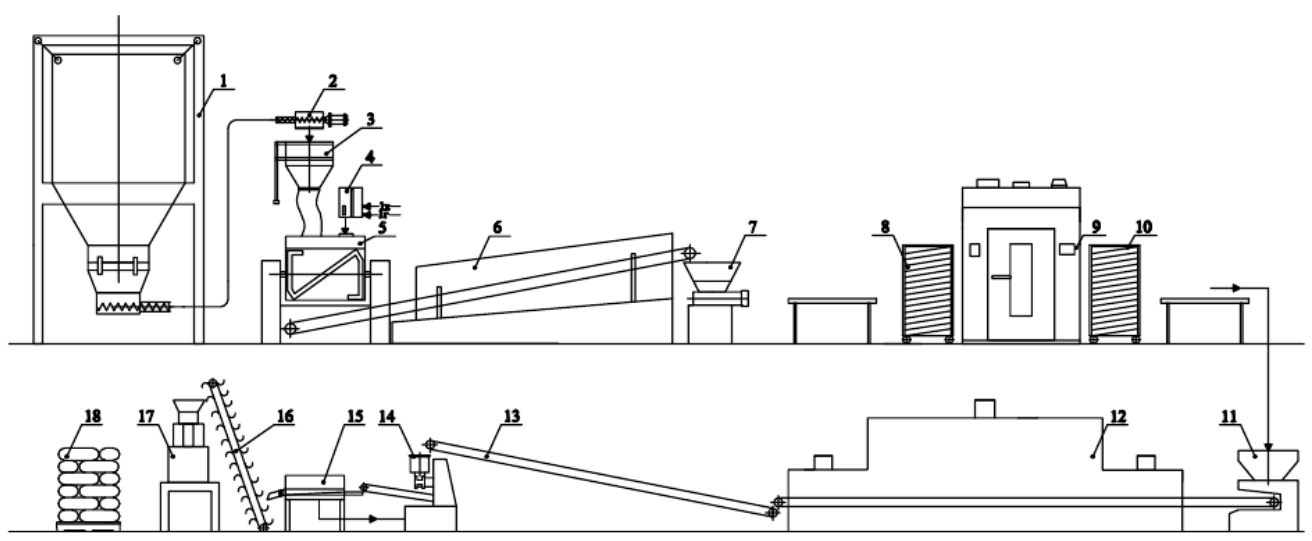

Рис. 2. Апаратурно-технологічна схема виготовлення спеціально випечених панірувальних сухарів: 1 - тканинний силос для зберігання борошна; 2 - пружинна транспортуюча система; 3 - автоматичний дозатор борошна; 4 - водомірний бачок; 5 - тістомісильна машина; 6 - камера для бродіння тіста; 7 - екструдер для формування тістових заготовок; 8 - вагонетка для випікання; 9 - піч ротаційного типу; 10 - вагонетка для охолодження виробів; 11 - подрібнювач; 12 - піч для крихти попереднього подрібнення; 13 - охолоджувальний конвеєр; 14 - млинок для остаточного подрібнення крихти; 15 - калібратор; 16 - ківшовий конвеєр; 17 - пакувальна машина; 18 - мішки з готовою продукцією.

Висновок. Використання запропонованої схеми забезпечить зростання потужності підприємства без необхідності збільшення виробничих площ, водночас зменшивши кількість важкої фізичної праці. Встановлення сучасного транспортуючого обладнання сприятиме суттєвому зменшенню технологічних втрат, підвищивши рентабельність виробництва. А можливість регулювання параметрів процесу на всіх етапах дасть змогу отримувати панірувальні сухарі з прогнозованими і наперед за- 
даними характеристиками, що відповідатимуть найвибагливішим запитам споживачів. Зокрема, значно стабілізується крупність як один 3 визначальних показників якості сухарної крихти (рис. 3).

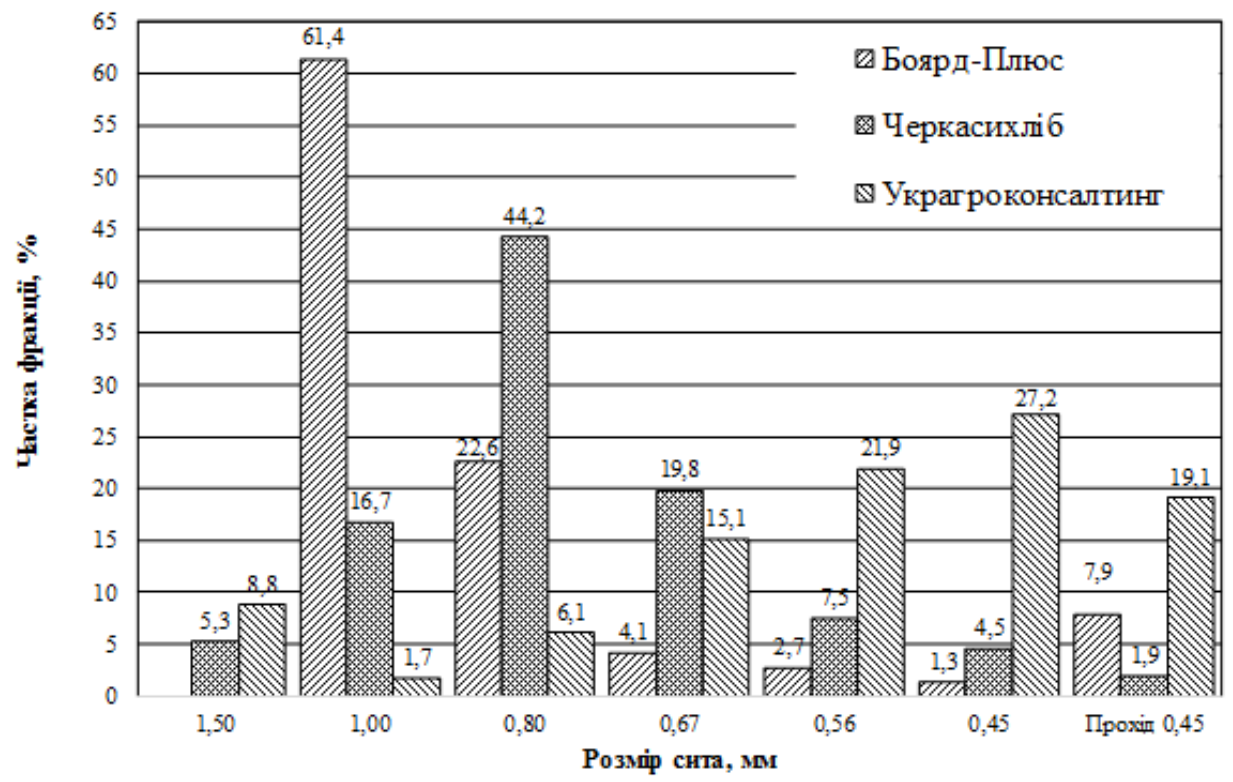

Рис. 3. Крупність (фракційних склад) панірувальних сухарів різних виробників

\title{
ЛITЕРАТУРА
}

1. Бондар Н. П. Удосконалення технології м'ясних січених напівфабрикатів з використанням харчових волокон люпину / Н. П. Бондар, Л. О. Шаран, В. О. Губеня, Ю. С. Дитюк // Наукові праці Національного університету харчових технологій. - 2016. - Т. 22, № 5. C. $214-221$.

2. Кишенько I. I. Оцінка впливу речовин кріопротекторної дії на показники якості посічених напівфабрикатів / І. І. Кишенько, О. І. Скочко // Харчова промисловість. - 2017. № 21. - С. 89 - 93 .

3. Паска М. 3. Контроль якості м'ясних функціональних котлет / М. 3. Паска, О. Б. Маслійчук // Наукові праці Національного університету харчових технологій. - 2018. T. 24, № 5. - C. 135-143.

4. Сухарі панірувальні. Загальні технічні умови: ДСТУ 8708:2017. — [Чинний від 201801-01]. - К.: ДП «УкрНДНЦ», 2018. - 14 с.

5. Махинько В. М. Оценка физических свойств крошки для производства сухарных брикетов / В. М. Махинько, Ф. Г. Самбурский, М. Д. Землинская // Научный взгляд в будущее. Выпуск 7, Том 1. - Одесса: Куприенко С. В., 2017. - С. 68-72.

\section{ОБОСНОВАНИЕ УСОВЕРШЕНСТВОВАННОЙ СХЕМЫ ПРОИЗВОДСТВА СПЕЦИАЛЬНО ВЫПЕЧЕННЫХ ПАНИРОВОЧНЫХ СУХАРЕЙ}

\author{
В. Н. Махинько, Л. В. Махинько, И. А. Мельник \\ Национальный университет пищевых технологий
}

Целью работы было выявление «узких мест» производства и разработки мероприятий и предложений по совершенствованию имеющейся аппаратурно-техно- 
логической схемы. На конкретном примере установлены основные ограничивающие фракторы производства и предложен ряд мер для их преодоления. Показано, что широкое внедрение механизации основных и вспомогательных операций обеспечит не только рост мощности предприятия, но и уменьшит количество тяжелого физического труда, даст возможность отказаться от работы в ночное время. Использование современного оборудования способно также существенно уменьшить технологические потери, повысив рентабельность производства. Использование предложенной схемы является перспективным и может быть внедрено как на крупных предприятиях, так и в цехах небольшой мощности. Ключевые слова: панировка, панировочные сухари, хлебная крошка, оборудование, технология, усовершенствование. 